\title{
Preconditioning with L-alanyl-glutamine reduces hepatic ischemia-reperfusion injury in rats ${ }^{1}$
}

\author{
Pré-condicionamento com L-alanil-glutamina reduz a lesão de isquemia-reperfusão no \\ fígado de ratos
}

\begin{abstract}
Raimundo José Cunha Araújo Júnior ${ }^{I}$, Raimundo Gerônimo da Silva Júnior ${ }^{\text {II }}$, Marcelo Pinho Pessoa de Vasconcelos ${ }^{\text {III }}$, Sérgio Botelho Guimarães $^{\mathrm{IV}}$, Paulo Roberto Leitão de Vasconcelos ${ }^{\mathrm{V}}$, José Huygens Parente Garcia ${ }^{\mathrm{VI}}$
\end{abstract}

IFellow MS Degree, Department of Surgery, Postgraduate Program, UFC, Ceara, Brazil. Technical procedures, acquisition and interpretation of data. The article is part of a master degree dissertation.

${ }^{I}$ MS, Head, Surgical Pathology and Cytology Laboratory (LAPAC), Piaui, Brazil. Technical procedures and interpretation of data.

"II Graduate student, Faculty of Medicine, UFC, Ceara, Brazil. Helped with technical procedures, acquisition of data.

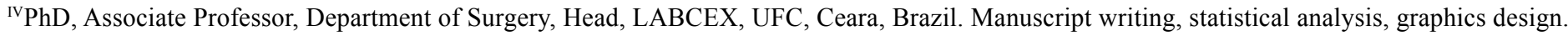
${ }^{v} \mathrm{PhD}$, Associate Professor, Coordinator, Postgraduate Program, Department of Surgery, UFC, Ceara, Brazi. Critical revision and analysis of data.

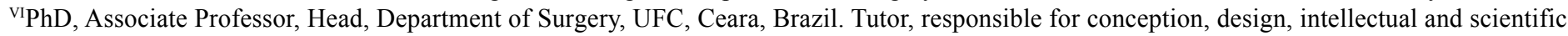
content of the study, critical analysis, final approval of manuscript.

\begin{abstract}
PURPOSE: To evaluate the effects of pre-conditioning with L-alanyl-glutamine (L-Ala-Gln) in rats subjected to total hepatic ischemia. METHODS: Thirty Wistar rats, average weight 300g, were randomly assigned to 3 groups (n=10): G-1 - Saline, G-2- L-Ala-Gln, G-3-control (Sham). G-1 and G-3 groups were treated with saline $2.0 \mathrm{ml}$ or L-Ala-Gln ( $0.75 \mathrm{mg} / \mathrm{Kg}$ ) intraperitoneally (ip) respectively, 2 hours before laparotomy. Anesthetized rats were subjected to laparotomy and total hepatic ischemia ( 30 minutes) induced by by clamping of portal triad. Control group underwent peritoneal puncture, two hours before the sham operation (laparotomy only). At the end of ischemia (G1 and G2), the liver was reperfused for 60 minutes. Following reperfusion blood samples were collected for evaluation of alanine aminotransferase (ALT) and lactate dehydrogenase $(L D H)$ levels. Liver (medium lobe) was removed for immunohistochemistry study with antibody for Caspase-3.

RESULTS: It was found a significant decrease $(\mathrm{p}<0.05)$ of ALT levels $(270.6+40.8$ vs $83.3+5.5-\mathrm{p}<0.05)$, LDH $(2079.0+262.4$ vs. $206.6+16.2-\mathrm{p}<0.05)$ and Caspase-3 expression $(6.72+1.35$ vs. $2.19+1.14, \mathrm{p}<0.05)$ in rats subjected to I / R, comparing the group treated with L-Ala -Gln with G-2. Also, the ALT level was significantly lower $(\mathrm{P}<0.05)$ in G-1 and G-2 groups than in G-3 (control group).
\end{abstract}

CONCLUSION: L-Ala-Gln preconditioning in rats submitted to hepatic I/R significantly reduces ALT, LDH and Caspase-3 expression, suggesting hepatic protection.

Keywords: Surgical Procedures, Operative. Ischemia. Reperfusion. Glutamine. Liver. Rats.

\section{RESUMO}

OBJETIVO: Avaliar os efeitos do pré-condicionamento com L-alanil-glutamina (L-Ala-Gln) em ratos submetidos à isquemia hepática total.

MÉTODOS: Trinta ratos Wistar, peso médio 300g foram divididos aleatoriamente em três grupos (n=10): G-1 - Saline, G-2: L-Ala-Gln, G-3: controle. G-1 e G-3 grupos foram tratados com 2,0 ml de solução salina ou L-Ala-Gln (0,75 mg / kg) intraperitoneal (ip), respectivamente, duas horas antes da laparotomia. Ratos anestesiados foram submetidos à laparotomia e isquemia hepática total (30 minutos) induzida por pinçamento da tríade portal. O grupo controle foi submetido à punção peritoneal, duas horas antes da operação simulada (apenas laparotomia). No final da isquemia, o fígado foi reperfundido por 60 minutos. As amostras de sangue foram colhidas ao término da reperfusão para determinação das concentrações alanina aminotransferase (ALT) e desidrogenase láctica (LDH). O lobo médio do fígado foi removido para estudo imuno-histoquímico com anticorpo para caspase-3.

RESULTADOS: Houve diminuição significante $(\mathrm{p}<0.05)$ dos valores de ALT $(270,6 \pm 40,8$ vs 83,3+5,5 - p<0,05), LDH $(2079,0 \pm 262,4$ vs 206,6 $\pm 16,2-\mathrm{p}<0,05)$ e expressão da Caspase-3 (6,72 $\pm 1,35$ vs 2,19 $\pm 1,14-\mathrm{p}<0,05)$ nos ratos submetidos à $\mathrm{I} / \mathrm{R}$, comparando o grupo tratado com L-Ala-Gln, ao grupo salina. Além disso, o nível de ALT foi significativamente menor (P $<0,05)$ no G-1 e G-2 do que no grupo G-3 (grupo controle). 
CONCLUSÃO: O pré-condicionamento com L-Ala-Gln em ratos submetidos a I/R hepática reduz significativamente as concentrações de ALT e LDH e a expressão da caspase-3, sugerindo proteção hepática.

Descritores: Procedimentos Cirúrgicos Operatórios. Isquemia. Reperfusão. Glutamina. Fígado. Ratos.

\section{Introduction}

Injuries secondary to hepatic ischemia occurring during liver transplant and resection procedures constitute a serious surgical problem. Interruption of blood flow (ischemia) followed by reflow (reperfusion), at the end of the surgical procedures, lead to important hepatic lesions, the so called ischemia-reperfusion injury $(\mathrm{I} / \mathrm{R})^{1,2}$. Strategies to prevent blood loss during hepatic resections include the total control of the influx of blood to the liver by Pringle ${ }^{3}$ maneuver or by selective occlusion of liver segment vessels.

Numerous substances, here included ranitidine 4 verapamil $^{5}$, cyclosporin ${ }^{6}$, lidocaine ${ }^{7}$, and erythropoietin ${ }^{8}$ have been used in an attempt to find the ideal drug for liver protection in the presence of $\mathrm{I} / \mathrm{R}$. Glutamine (GLN) is the most abundant amino acid in the body and it plays an important role in regulating acidbase balance, promoting immune function, and improving adaptation to stress ${ }^{9,10}$. Also, GLN is the precursor of glutathione (GSH), one of the most important antioxidants in the body ${ }^{11}$.

An article published recently shows that preconditioning with GLN protects the liver from I/R damage, when subjected to ischemia for one hour followed by reperfusion for 2 hours ${ }^{12}$. Whereas the studies cited, this study was aimed to evaluate the effects of preconditioning with L-Ala-Gln in rat livers subjected to ischemia for 30 minutes followed by reperfusion for 60 minutes, on indicators of liver injury (ALT, LDH) and the expression of Caspase-3.

\section{Methods}

Approval for experimental use of laboratory animals was obtained on 30/09/2008 (Protocol \#37/08) from the Ethics Committee on Animal Research (CEPA) of the Federal University of Ceara, now Ethics Committee on the Use of Animals (CEUA), in view of the Federal Law No. 11794 of October 8, 2008, http:// www.planalto.gov.br/ccivil_03/_Ato2007-2010/2008/Lei/ L11794.htm and Decree No. 6689 of July 15, 2009 that regulated the Law 11794, available at: http://www.planalto.gov.br/ccivil_03/ Ato2007-2010/2009/Decreto/ D6899.htm. The study was designed so as to minimize the number of animals required for the experiments.

Study groups consisted of male Wistar rats, provided by the Faculty Novafapi (Teresina-PI, Brazil). Rats were housed in polypropylene cages at ambient temperature of $24^{\circ}$ on a $12 \mathrm{~h}$ lightdark cycle and allowed free access to food (Purina chow) and water. Thirty Wistar rats, average weight $300 \mathrm{~g}$, were randomly assigned to 3 groups $(n=10)$ : G-1 - Saline, G-2: L-Ala-Gln, G-3: control (Sham). G-1 and G-3 groups were treated with saline $2.0 \mathrm{ml}$ or LAla-Gln, Dipeptiven ${ }^{\circledR}(0.75 \mathrm{mg} / \mathrm{Kg})$ intraperitoneally (ip) respectively, 2 hours before laparotomy. Anesthetized rats were subjected to laparotomy and total hepatic ischemia (30 minutes) induced by clamping of portal triad. Control group underwent peritoneal puncture, two hours before the sham operation (laparotomy only). At the end of ischemia, the liver was reperfused for 60 minutes. Following reperfusion blood samples were collected for assessment of alanine aminotransferase (ALT) and lactate dehydrogenase $(L D H)$ levels. Liver (medium lobe) was removed for immunohistochemistry study with antibody for Caspase-3.

\section{Chemicals and drugs}

L-Ala-Gln (Dipeptiven ${ }^{\circledR}$ ) was purchased from Frenesius Kabi Áustria GmbH Graz/Áustria. All other chemicals were purchased from standard commercial sources and were of the highest quality available.

Biochemical analysis

Biochemistry of LDH (automated kinetic) and ALT (UV Kinetic) were measured from dry chemistry kits, Ortho Clinical Vitros analyzer in 250 Chemistry System (WS-JJ250), Rochester, NY, USA

\section{Immunohistochemistry}

Formalin-fixed tissues were cut $5 \mu \mathrm{m}$ thick and mounted on glass slides previously pre-coated with poly-D-lysine adhesive (Sigma Chemical Corporation, p-7886). Proliferative activity and apoptosis were evaluated by immunohistochemistry, using the antiCDC47 Clone 47DC141 and anti-caspase-3 clone RB-1197-P (NeoMarkers), respectively. The sections were subjected to the technique of streptavidin-biotin-peroxidase (Ultravision large volume detection system anti-polyvalent, HRP, Lab Vision). Antigen retrieval was carried out using a retrieval solution (Dako, California, USA) for 20 minutes. Glass slides were incubated in a moist chamber for one hour with each primary antibody separately (CDC47 - dilution of 1:200 or caspase 3 - 1:300) (Novocastra Laboratories), SBP (estreptavidina-biotina peroxidase) and for 15 minutes in steps of blocking endogenous peroxidase, blocking serum (Lab Vision) secondary antibody (Biotin Goat, Lab Vision) and streptavidin-biotin-peroxidase. We used the DAB (Lab Vision) as chromogen, incubating for ten minutes, and Harris hematoxylin as counterstain. 


\section{Surgical procedure}

The rats were fasted for 12 hours the night before the experiment. Surgical procedures were performed under anesthesia by intraperitoneal (IP) with a solution of ketamine hydrochloride, $80 \mathrm{mg} / \mathrm{kg}$ (Cristália) + xylazine hydrochloride, $10 \mathrm{mg} / \mathrm{kg}$ (Bayer $\mathrm{SA}$ ). Access to the hepatic pedicle was obtained through a midline incision (laparotomy). The triad, composed of the portal vein, hepatic artery and bile duct was isolated and was subsequently occluded with bulldog vascular clamp (Figure 1) and the abdominal wall was closed. After a period of 30 minutes of ischemia, the abdomen was reopen and the clamp was removed, restoring the blood flow. The abdomen was closed, allowing hepatic reperfusion for a period of 60 minutes. At the end of the reperfusion, blood samples were collected by cardiac puncture for ALT and LDH assays. The medium lobe of the liver was removed for imunohistochemistry study with caspase -3 marker.

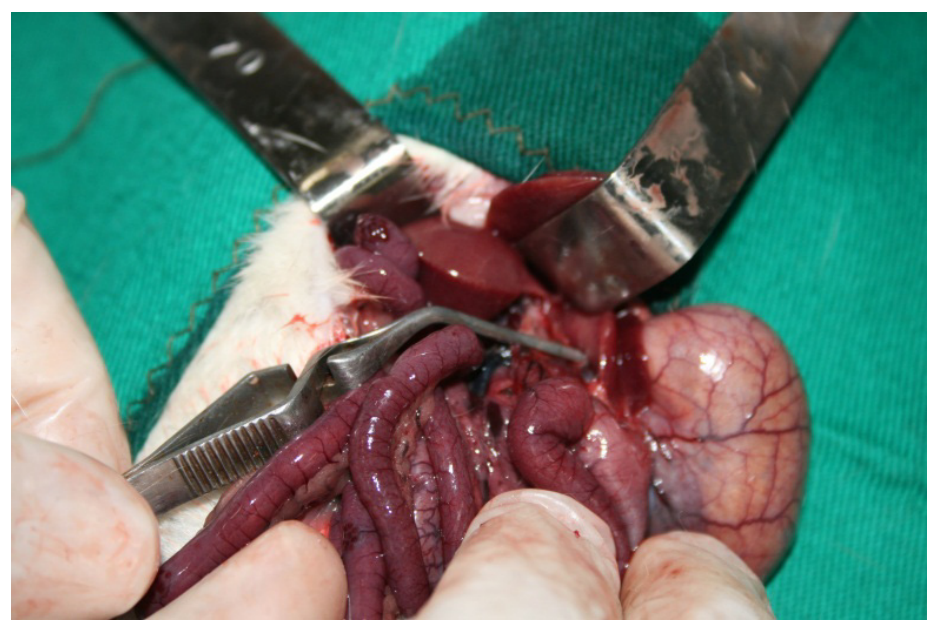

FIGURE 1 - Details of the hepatic pedicle clamping to induce total hepatic ischemia by applying a Bulldog vascular clamp in group 2 (Ischemia/reperfusion) rats.

\section{Immunohistochemical evaluation criteria}

The computer program Rel 42.-Zeiss Axiovision was used to capture field images with labeling of cells stained in brown (immunohistochemical expression of caspase 3 ), the score in twenty random fields and relative percentage of unstained cells). Results were presented as means \pm standard deviation (SD).

\section{Statistical methods}

Graphpad Prism 5.0 (GraphPad Software, www.graphpad.com) was used for statistical analysis and graphics design. All data were tested for distribution by applying the Kolmogorov-Smirnov test. Multiple comparisons were made using one-way ANOVA followed by Tukey's post-test. Values of $\mathrm{p}<0.05$ were accepted as statistically significant.

\section{Results}

No animal died during the experiment. Results are presented figures and graphs. ALT concentrations increased significantly in $\mathrm{G}-2(\mathrm{p}<0.01)$ and decreased significantly in LAla-Gln treated rats $(\mathrm{p}<0.001)$ (Figure 2).

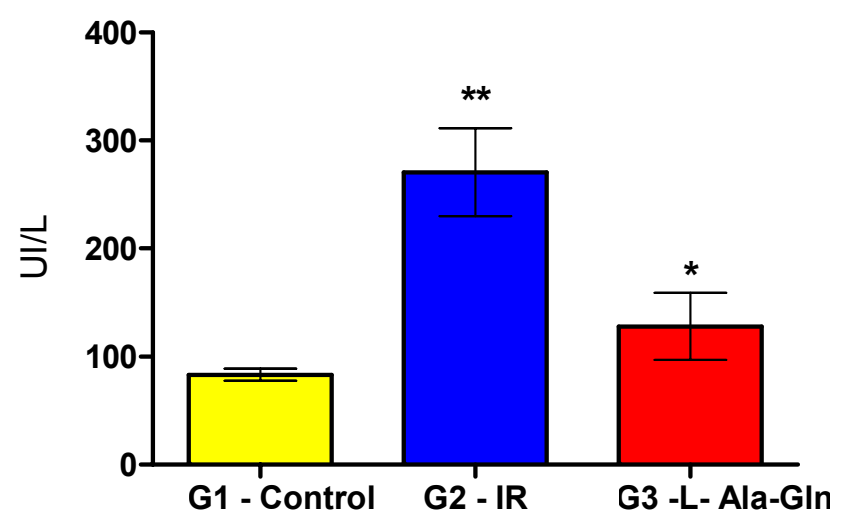

FIGURE 2 - Aminotransferase (ALT) concentrations (units/Liter) in blood serum of G-1 (Control), G-2 (Ischemia/reperfusion) and G-3 (Ischemia/reperfusion+L-Ala-Gln) rats. Bars represent mean $\pm \mathrm{SD}$ of G-1 (yellow bars), G-2 (blue bars) and G-3 (red bars) groups at the end of the reperfusion. G-3 group is significantly different from control group by ANOVA test. ${ }^{*} P<0.05$ compared with control group.

LDH concentrations increased significantly in G-2 $(\mathrm{p}<0.01)$ and decreased significantly in L-Ala-Gln treated rats $(\mathrm{p}<0.001)$ (Figure 3).

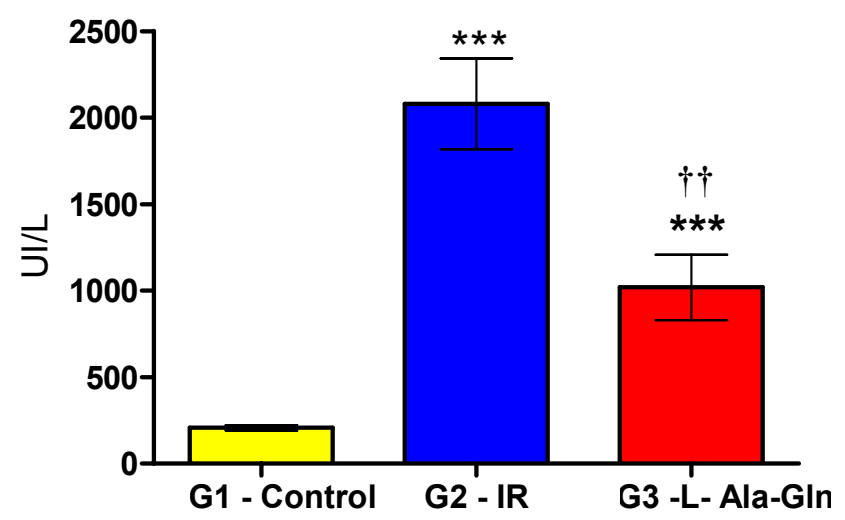

FIGURE 3 - Lactic dehydrogenase (LDH) concentrations (units/Liter) in blood serum of G-1 (Control), G-2 (Ischemia/reperfusion) and G-3 (Ischemia/reperfusion+L-Ala-Gln) rats. Bars represent mean $\pm \mathrm{SD}$ of G-1 (yellow bars), G-2 (blue bars) and G-3 (red bars) groups at the end of the reperfusion. G-3 group is significantly different from G-2 $(P<0.01)$ and control group $(P<0.001)$. G-2 group is significantly different from control group $(P<0.001)$. ANOVA test. 
Apoptosis increased significantly in G-2 rats $(\mathrm{p}<0.05)$. G-3 and G-1 values were not different (Figure 4).

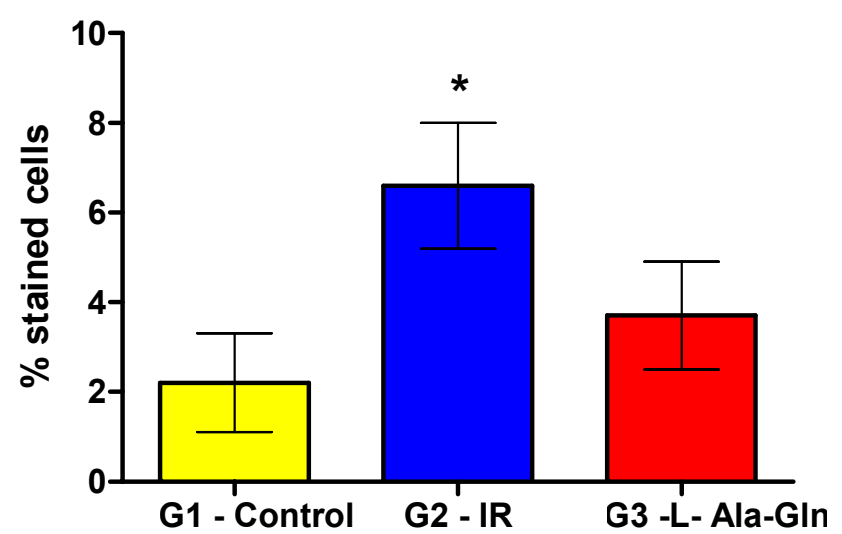

FIGURE 4 - Percentage of cells marked with caspase-3 in the liver of G-1 (Control), G-2 (Ischemia/reperfusion) and G-3 (Ischemia/ reperfusion $+\mathrm{L}-\mathrm{Ala}-\mathrm{Gln}$ ) rats. Bars represent mean $\pm \mathrm{SD}$ of G-1 (yellow bars), G-2 (blue bars) and G-3 (red bars) groups at the end of the reperfusion. G-2 group is significantly different from control group by ANOVA test. $* P<0.05$ compared with control group.

Figures 5, 6, and 7 depict caspase-3 expression as brown stained cells, in groups Control (G-1), ischemia/reperfusion (G-2) and ischemia/reperfusion + L-Ala-Gln (G-3).

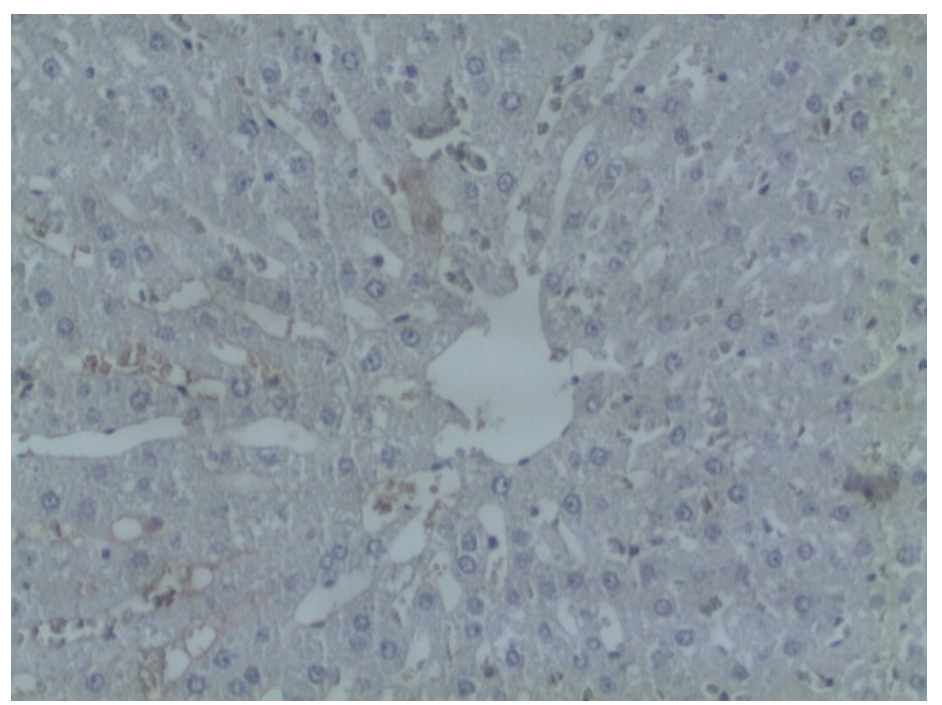

FIGURE 4 - Liver. Photomicrograph displaying rare apoptotic cells identified by brown staining in a rat of the Control (G-1) group. Immunohistochemistry. 200X.

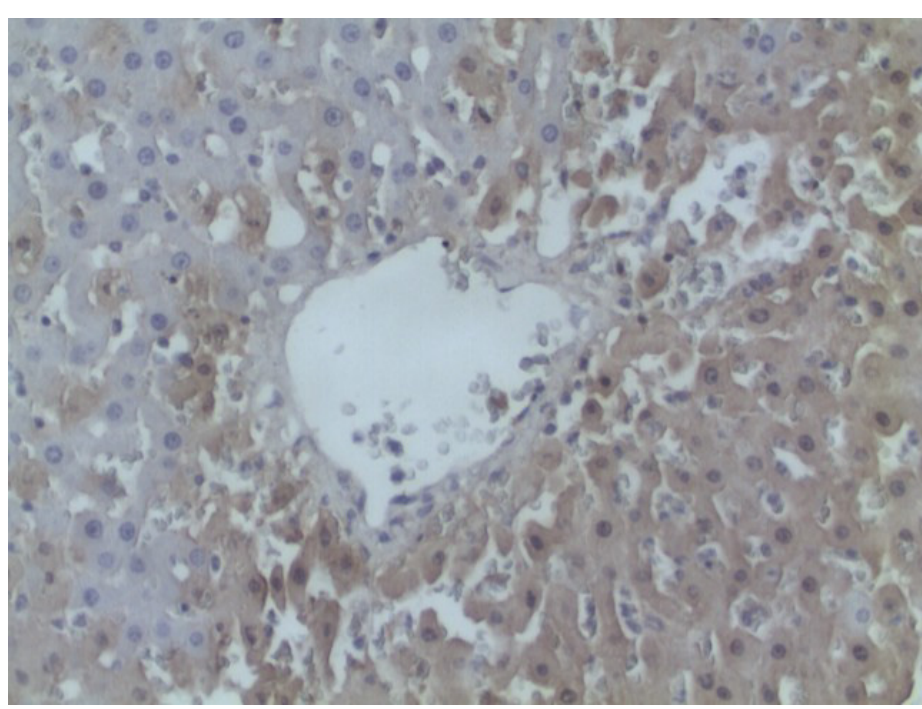

FIGURE 5 - Liver. Photomicrograph displaying large number of apoptotic cells identified by brown staining in a rat of the Ischemia/ Reperfusion (G-2) group. Immunohistochemistry. 200X.

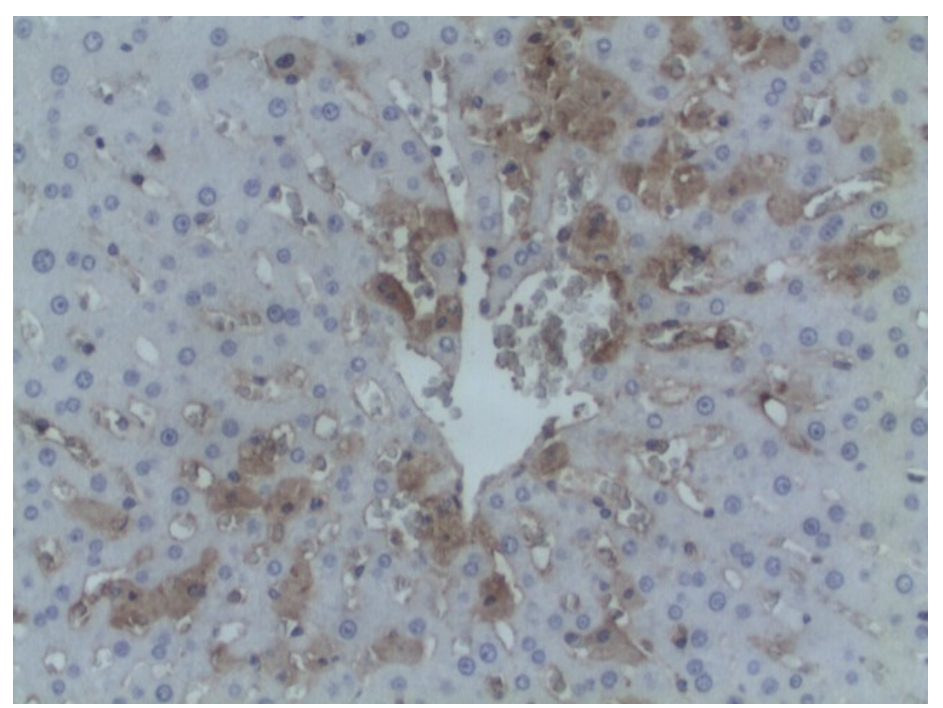

FIGURE 6 - Liver. Photomicrograph displaying moderate number of apoptotic cells identified by brown staining in a rat of the L-Ala-Gln (G-3) group. Immunohistochemistry. 200X.

\section{Discussion}

The liver is very sensitive to the effects of ischemia. It only takes 20 minutes to emerge the first indications of liver injury. Sebé et al. ${ }^{13}$ studied the effects of different times of hepatic ischemia in rats and concluded that the earliest cellular lesions appeared after 20 minutes and became more marked after 30 minutes. In the present study ischemia time was 30 minutes. Whereas no animals died during the experiment, one can say that this model is safe for 
the study of total hepatic ischemia. Moreover, the occurrence of increased levels of ALT and LSH enzymes in the ischemic rat confirms the hepatic triad clamping simulates the conditions where liver ischemia is present.

Studies by Clavien et al. ${ }^{14}$ disclosed the beneficial effect of the ischemic preconditioning in partial liver resections with vascular exclusion. ALT and LDH levels increased significantly in ischemic livers except in those organs removed from animals submitted to ischemic preconditioning. In our study the significant increase in ALT and LDH levels occurred in rats submitted to I/R. Rats preconditioned with L-Ala-Gln showed a significant decrease in ALT and LDH levels. These evidences demonstrate that in some way the preconditioning with L-Ala-Gln may reduce tissue damage in the ischemic liver.

Animal studies demonstrated that the depletion of glutathione (GSH) increases apoptosis in cholangiocytes ${ }^{15}$. Hong et al. ${ }^{16}$ have demonstrated that the GLN supplementation increases hepatic GSH supplies in the model of total hepatic Ischemia for 30 minutes, followed of a period of reperfusion for 60 minutes. Jia et $a l .{ }^{17}$ have indicated that after 30 minutes of ischemia, the function and hepatic morphology are harmed and that the pretreatment with GLN could grant protection against the damage of the liver. However, the accurate mechanism of protective effect of the GLN against the I/R injury of organs and tissue is not yet completely understood. GLN protects against I/R injury in the intestine, heart and skeletal muscle by preserving the content of GSH in those tissues ${ }^{18}$.

Apoptosis or programmed cell death is a process to eliminate damaged or abnormal cells in multicellular organisms, and it represents a common mechanism of cell replacement and tissue remodeling ${ }^{20}$. Apoptosis can be triggered by external stimuli through specific receptors on the cell surface (death receptors) or internal stimuli to intracellular stress, such as DNA damage or changes in cell cycle or in metabolic pathways. These different pathways culminate in the activation of proteases known as caspases, which play a key role in the process of cell death ${ }^{21}$. The absence of significant differences between groups G-1 and G-3, resulting from statistical analysis of the number of stained cells, representing those cells that express the caspase- 3 protease in liver tissue shows that the use of L-Ala-Gln may offer the expected protective effect, reducing apoptosis in the liver subjected to I/R. On the other hand the increase in the apoptosis index in G-2, compared with control group, shows that the study model used here induces injuries in liver of rats submitted to hepatic triad clamping for 30 minutes followed by reperfusion for 60 minutes.

The results obtained from different studies are contradictory. Hong et al. ${ }^{16}$ demonstrated that pretreatment with GLN diminished the frame number in necrosis and increased in apoptosis. Noh et al. ${ }^{22}$ studied the effect of pretreatment with GLN in hepatic $\mathrm{I} / \mathrm{R}$ in rats and concluded that pretreatment with the aminoacid did not reduce hepatic ischemia/reperfusion injury. Schuster et $a l .{ }^{23}$ demonstrated the protective effect of the GLN dipeptide and vitamin $\mathrm{E}$ against the hepatic ischemia reperfusion injury. ${ }^{23}$ The association of GLN with vitamin $\mathrm{E}$ induced a reduction of inflammatory response and oxidative stress, resulting in better preservation of hepatic GSH content. The result is a higher viability of liver after I/R injury ${ }^{23}$. The results of this study show that GLN preconditioning may reduce cellular lesions due to hepatic total ischemia for a period of 30 minutes. However, considering that the mechanisms of action of GLN in reducing hepatic I/R lesions have not been fully elucidated there is a need for further studies.

\section{Conclusion}

L-Ala-Gln preconditioning in rats submitted to hepatic I/ R significantly reduces ALT, LDH and Caspase-3 expression, suggesting hepatic protection.

\section{References}

1. Miranda LE, Viaro F, Ceneviva R, Evora PRB. As bases experimentais da lesão por isquemia e reperfusão do fígado. Acta Cir Bras. 2004;19(1):3-12.

2. Silva OC, Centurion S, Pacheco EG, Brisotti JL, Oliveira AF, Sasso KD. Aspectos básicos da lesão de isquemia e reperfusão e do précondicionamento isquêmico. Acta Cir Bras. 2002;17(Suppl. 3):96-100.

3. Pringle JH. Notes of the arrest of hepatic hemorrhage due to trauma. Ann Surg. 1908;48(4):541-9.

4. Okajima K, Okajima K, Harada N, Uchiba M. Ranitidine reduces ischemia/reperfusion-induced liver injury in rats by inhibiting neutrophil activation. J Pharmacol Exp Ther. 2002;301 (3):1157-65.

5. Yagmurdur MC, Ozdemir A, Topaloglu S, Kilic K, Ozenc A. Effects of alpha tocopherol and verapamil on liver and small bowel following mesenteric ischemia-reperfusion. Turk J Gastroenterol. 2002;13(1):40-6. 6. Garcia JHP, Coelho GR, Sousa IT, Siqueira RP, Vasconcelos PRL. Alterações metabólicas induzidas por isquemia hepática normotérmica experimental e o efeito hepatoprotetor da ciclosporina. Arq Gastroenterol. 2004;41(1):54-8.

7. Chen My, Li CH, Huang Zq, Liu JC, Zhou NX, Huang XQ, Wang YS. Protective effects of lidocaine injected into the hepatoduodenal ligamento $\mathrm{n}$ warm ischemia-reperfusion injury to the rat liver. Chin Med J. 2004;117(2):275-9.

8. Luo YH, Li ZD, Liu LX, Dong GH. Pretreatment with erythropoietin reduces hepatic ischemia-reperfusion injury; Hepatobiliary Pancreat Dis Int. 2009;8(3):194-9.

8. Novak F, Heyland DK, Avenell A, Drover JW, Su X. Glutamine supplementation in serious illness: a systematic review of the evidence. Crit Care Med. 2002;30(9):2022-9.

9. Melis GC, ter Wengel N, Boelens PG, van Leeuwen PA. Glutamine: recent developments in research on the clinical significance of glutamine. Curr Opin Clin Nutr Metab Care. 2004;7(1):59-70.

10. Wischmeyer PE, Jayakar D, Williams U, Singleton KD, Riehm J, Bacha EA, Jeevanandam V, Christians U, Serkova N. Single dose of glutamine enhances myocardial tissue metabolism, glutathione content, and improves myocardial function after ischemia-reperfusion injury. JPEN J Parenter Enteral Nutr. 2003;27(6):396-403.

11. Wilmore DW. The effect of glutamine supplementation in patients following elective surgery and accidental injury. J Nutr. 2001;131(9 Suppl):2543S-9S.

12. Zhang WX, Zhou LF, Zhang L, Bao L, Wang CC, Meng HY, Yin W. Protective effects of glutamine preconditioning on ischemia-reperfusion injury in rats. Hepatobiliary Pancreat Dis Int. 2011;10(1):78-82. 
13. Sébe AA, Gomes PO, Nigro AJT, Simões MJ, Novo NF, Juliano Y. Efeitos de diferentes tempos de isquemia no fígado de ratos. Acta Cir Bras. 2000;15 (Suppl.1):29-29.

14. Clavien PA, Yadav S, Sindram D, Bentley RC. Protective effects of ischemic precontioning for liver resection performed under inflow occlusion in humans. Ann Surg. 2000; 232(2):155-62.

15. Parolin MB, Reason IJ. Apoptose como mecanismo de lesão das doenças hepatobiliares. Arq Gastroenterol. 2001;38(2):138-44.

16. Hong RW, Rounds JD, Helton WS, Robinson MK, Wilmore DW.

Glutamine preserves liver glutathione after lethal hepatic injury. Ann Surg. 1992;215(2):114-9.

17. Jia CJ, Dai CL, Zhang X, Cui K, Xu F, Xu YQ. Alanyl-glutamine dipeptide inhibits hepática ischemia-reperfusion injury in rats. World $\mathrm{J}$ Gastroenterol. 2006;12(9):1373-8.

18. Prem JT, Eppinger M, Lemmon G, Miller S, Nolan D, People J. The role of glutamine in skeletal muscle ischemia/reperfusion injury in the rat hind limb model. Am J Surg. 1999;178(2):147-50.
19. Xue F, Wang G, Pang Z, Liu C, Liang T. Protective effect of glutathione against liver warm ischemia-reperfusion injury in rats is associated with regulation of P-selectin and neutrophil infiltration. Anat Rec (Hoboken). 2008;291(8):1016-22.

20. Taraphdar AK, Roy M, Bhattacharya RK. Natural products as inducers of apoptosis: implication for cancer therapy and prevention. Curr Sci. 2001;80(11):1387-96.

21. Patel T. Apoptosis in hepatic pathophysiology. Clin Liver Dis. 2000;4(2):295-317.

22. Noh J, Behrends M, Choi S, Bedolli MA, Yardi J, Hirose R, Niemann $\mathrm{CU}$. Glutamine does not protect against hepatic warm ischemia/ reperfusion injury in rats. J Gastrointest Surg. 2006;10(2):234-9.

23. Schuster H, Blanc MC, Bonnefont-Rousselot D, Nakib S, Le Tourneau A, Fürst P, Cynober L, De Bandt JP. Protective effects of glutamine dipeptide and alpha-tocopherol against ischemia-reperfusion injury in the isolated rat liver. Clin Nutr. 2009;28(3):331-7.

\section{Correspondence:}

Paulo Roberto Leitão de Vasconcelos

Rua Professor Costa Mendes, 1608/3 andar, Bloco Didático

60430-140 Fortaleza - CE Brasil

Tel.: (55 85)3366-8083

Fax: (55 85)3366-8064

paulo.vasconcelos@ufc.br

Conflict of interest: none

Financial source: none

${ }^{1}$ Research performed at the Experimental Surgery Research Laboratory (LABCEX), Department of Surgery, Federal University of Ceara (UFC) and Experimental Surgery Laboratory, Novafapi Faculty, Teresina-PI, Brazil. 